\title{
Aspects influence leachate characteristics on leachate treatment plants in Temesi Landfill Gianyar Regency, Bali Province, Indonesia
}

\author{
Ayu Putri Pradwi Sukma ${ }^{1, *}$, Wardiha Made Widiadnyana ${ }^{2}$ \\ ${ }^{1}$ Junior Researcher, Balai Litbang Perumahan Wilayah II Denpasar, R\&D Agency, Ministry of Public Works \\ ${ }^{2}$ Young Researcher, Balai Litbang Perumahan Wilayah II Denpasar, R\&D Agency, Ministry of Public Works
}

\begin{abstract}
This paper revealed aspects that influenced leachate characteristics in leachate treatment plants located in Temesi landfill. Four aspects observed refers to Law Number 3/2013 Ministry of Public Works: landfill operation; rainfalls; treatment plant designs; operation and maintenance. Data collected by observation and field survey to identify leachate characteristics. Leachates were collected by grab sampling from inlet through outlet of the treatment plants, to be laboratory analysed to meet the standards set by Ministry of Environmental and Forestry Number 59/2016 and compared to the standards. Leachate discharge calculated using Thornthwaite method to be compared to criteria designed. The result shown that leachate discharge is $0.45 \mathrm{~L} / \mathrm{sec}$ exceeding the designed discharge $0.42 \mathrm{~L} / \mathrm{sec}$. Laboratory test result from leachate sampling shown that the BOD, COD and TSS value exceeding the regulation standard in range of $>2000 \mathrm{mg} / \mathrm{L}$. Findings revealed that the depth of maturation ponds is 2.9 meters exceeded the designed criteria. It is found that the landfill operated with open dumping system and the treatment lagoons has never been regularly drained and recirculate. Those practices increase the leachate volume and degenerate the treatment functions. It can be concluded that the 4 aspects mentioned significantly influenced the leachate characteristics.
\end{abstract}

\section{Introduction}

Sanitary landfills are the most widely utilized method for solid wastes disposal around the world [1], the method also widely used in most municipalities in Indonesia [2]. The shortcoming from landfill practiced is the leachate generations, leachate may be defined as liquid that has percolated through solid waste and has extracted dissolved or suspended material [3]. If the leachate generations are not treated carefully, this leachate can cause considerable pollution problems by contaminating the surrounding soil, ground or surface waters (4].

Commonly, most leachate generates by landfills in Indonesia were implementing the leachate treatment plant. And due to its reliability, simplicity and high costeffectiveness, biological treatment with suspended/attached growth is commonly used for the removal of the bulk of leachate containing high concentrating organics [4] such as BOD and COD. In some case, the leachate treatment also combines with leachate recycling.

Nevertheless, most leachate treatment practiced continuing generates leachate that exceeded the standard regulation. From leachate characteristics sampling conducted in west and central parts of Indonesia, it is found that 8 out of 10 landfills contained BOD and COD exceeding the quality standards [5]. These findings confirmed that further investigation is needed to find the cause.

Leachate treatment plants design is predominantly determined from the landfill leachate characteristics. Temesi landfill is one of landfill facility located in Bali. From early investigation, it is found that this landfill was already overloaded which is the solid waste volume approximately $661.2 \mathrm{~m}^{3} /$ day surpassing the target maximum $419 \mathrm{~m}^{3} /$ day. Leachate treatment plants in this landfill in improperly condition which is shown the exceed leachate from pipes and it has yellow-brown colour. From this situation, it is important to conducting investigation in Temesi landfill to identify the problems particularly identifying the leachate characteristics.

Therefore, due to solve the current issue, this study aimed to investigate aspects influenced leachate characteristics generates from leachate treatment plant in order to be able to meet the leachate quality standards established by Ministry of Environment and Forestry number $p .59$ year 2016 [6].

\section{Regulation standards}

* Corresponding author: pradwi.sukma@puskim.pu.go.id 


\subsection{Law number p.59 year 2016 Ministry of Environmental and Forestry}

The standard used as benchmark to verify the leachate quality from the treatment plant leachate sampling is achieving the standards. As seen in Table 1.

Table 1. Leachate quality standards [6]

\begin{tabular}{|c|c|c|}
\hline \multirow{2}{*}{ Parameters } & \multicolumn{2}{|c|}{ Maximum Level } \\
\cline { 2 - 3 } & Value & Unit \\
\hline $\mathrm{pH}$ & $6-9$ & - \\
\hline $\mathrm{BOD}$ & 150 & $\mathrm{mg} / \mathrm{L}$ \\
\hline $\mathrm{COD}$ & 300 & $\mathrm{mg} / \mathrm{L}$ \\
\hline $\mathrm{TSS}$ & 100 & $\mathrm{mg} / \mathrm{L}$ \\
\hline $\mathrm{N}$ total & 60 & $\mathrm{mg} / \mathrm{L}$ \\
\hline Mercury & 0.005 & $\mathrm{mg} / \mathrm{L}$ \\
\hline Cadmium & 0.1 & $\mathrm{mg} / \mathrm{L}$ \\
\hline
\end{tabular}

\subsection{Law number 3 year 2013 Ministry of Public Works [7]}

The standard used as the study parameter to aspects that influence the leachate characteristics in treatment plants. From Article number 49 clausal 2 stated that degradation of leachate pollutants influenced by: (a) landfill operational process; (b) rain fall; (c) dimension and penetration of leachate treatment plants; (d) detention time.

The standard also used as benchmark to verify the criteria design for leachate treatment plant applied in Temesi landfill. It is clearly stated in appendix chapter; point 1.5 regarding landfill facilities and infrastructure clausul number 2.b.2 regarding the leachate treatment.

\section{Methodologies}

\subsection{Preparation stage}

\subsubsection{Government institution permit}

There are two governments Institution that required permission in this study, they are: a) Work Unit Development of Environmental Sanitation Settlement in Bali Province, stakeholder who is authorized for leachate treatment plant in Temesi Landfill; b) environmental service of Gianyar Regency, stakeholder who is authorized for the Temesi landfill leachate treatment plant management.

\subsubsection{Designing instruments}

To achieve the research goals, instruments were designed as tools for data collecting.

\subsection{Applied instruments}

Instrument applied in the study as followed:

1) Leachate sampling form, consist of:

- Leachate treatment plant sketch draw and sampling point form

- Dimension, $\mathrm{pH}$ and temperature measurement form in each treatment lagoon

2) Leachate sampling tools

\subsubsection{Data collecting stage}

There are two identified aspects of leachate characteristics comprise of:

a) Leachate quantity measurement

To identify leachate quantity (debit) from treatment plants in Temesi landfill, the study applied Thornthwaite water balance method. It is a widely used method for estimating potential evaporation [8]. The method is based on assumption that leachate merely derived from rainfall that infiltrate into the waste generations [9]. There are three main steps in Thornthwaite equation [8].

Step 1: the annual value of the heat index (I) is calculated by summing monthly indices over a 12 month period. The monthly indices are obtained from equation

$$
i=\left(\frac{T_{a}}{5}\right)^{1,514}
$$

And

$$
\mathrm{I}=\sum_{j=1}^{12} i_{j}
$$

In which $\mathrm{Ta}\left({ }^{\circ} \mathrm{C}\right)$ is the mean monthly air temperature, $\mathrm{j}$ is the number of the month $(1-12), \mathrm{i}_{\mathrm{j}}$ is the monthly heat index for the month $\mathrm{j}$ (which is zero when the mean monthly temperature is $0^{\circ} \mathrm{C}$ ).

Step 1 preparation as followed:

1. Preparation of climatology data (10 year latest) as primary data in Thorntwaite method, consist of:

- Monthly rainfall data/precipitation

- Monthly air temperature data

- Weather station geography position

2. Monthly mean calculation of climatology data obtained ( 10 years average in monthly)

Step 2: calculates the unadjusted monthly values of potential evapotranspiration ETp $(\mathrm{mm})$ based on standard month of 30 days, with 12 hour of sunlight per day [8]. With equation:

$$
E T_{p}=C \cdot\left(\frac{10 \cdot T m}{I}\right)^{a}
$$

In which $\mathrm{C}$ is permeability coefficient (1.62), $\mathrm{Tm}$ is mean monthly temperature, and $a$ is constant $=6.7 \times 10^{-8} \cdot \mathrm{I}^{3}-77.1 \times 10^{-6} \cdot \mathrm{I}^{2}+0.01792 \cdot \mathrm{I}+0,492$

The value of exponent $a$ in the preceding equation varies from zero to 4.25 [8], the annual heat index (I) varies from zero to 160 , and ETp is zero for 0 temperature.

Step 3: the unadjusted monthly evapotranspiration value ETp are adjusted depending on the number of days $\mathrm{N}$ in a month $(1 \leq \mathrm{N} \leq 31)$ and the duration of daily 
daylight $d$ / daylight factor (hour). Calculation of adjusted Potential Evapotranspiration using equation:

$$
=P E T_{\text {unadjusted }} \times \text { monthly adjusted coefficient }
$$

Step 3 detailing as followed:

1. Calibrating season and latitude of adjustment coefficient

2. Specified monthly daylight factor from monthly adjustment coefficient

3. Calculation of Potential Evapotranspiration (PET) adjusted with preceding equation

To proceed to the next calculations, there are several parameters obtained from given data from the landfill criteria designed and also approximate empirical data.

To attain soil moisture storage in the water balance method, available water is concerned. The amount of available water that can be stored in a landfill will depend on the depth of the root zone, the soil type and structure. Also to calculate infiltration, some fraction of the incident precipitation will runoff the site and flow is lost before it has a chance to infiltrate. The approach used is to apply empirical runoff coefficients [10]. These two empirical parameters display in Table 2 and Table 3 as followed:

Table 2. Soil moisture ( $\mathrm{mm} / \mathrm{m})[10]$

\begin{tabular}{|c|c|c|c|}
\hline Type of soil & $\begin{array}{c}\text { Field } \\
\text { capacity }\end{array}$ & $\begin{array}{c}\text { Wilting } \\
\text { point }\end{array}$ & $\begin{array}{c}\text { Available } \\
\text { water }\end{array}$ \\
\hline Fine sand & 120 & 20 & 100 \\
\hline Sandy loam & 200 & 50 & 150 \\
\hline Silty loam & 300 & 100 & 200 \\
\hline Clay loam & 375 & 125 & 250 \\
\hline Clay & 450 & 150 & 300 \\
\hline
\end{tabular}

Table 3. Runoff coefficients [11]

\begin{tabular}{|c|c|}
\hline Surface conditions & Runoff coefficient \\
\hline $\begin{array}{c}\text { Grass cover: } \\
\text { Sandy soil, flat, 2\% }\end{array}$ & $0.05-0.10$ \\
\hline Sandy soil, average, 2-7\% & $0.10-0.15$ \\
\hline Sandy soil, steep, 7\% & $0.15-0.20$ \\
\hline Heavy soil, flat 2\% & $0.13-0.17$ \\
\hline Heavy soil, average, 2-7\% & $0.18-0.22$ \\
\hline Heavy soil, steep, 7\% & $0.25-0.35$ \\
\hline
\end{tabular}

4. Calculation of Infiltration value

$$
I=P \times C r o
$$

5. Calculation of Water storage

$$
I-P E T_{\text {adjusted }}
$$

6. Calculation of Potential Water Loss (APWL)

In wet season $(\mathrm{P}>\mathrm{PE}) \mathrm{APWL}$ value $=0$

In dry season $(\mathrm{P}<\mathrm{PE})$ APWL value obtain by adding the monthly deviation (P-PE) to (P-PE) previous month value.

7. Soil Moisture Storage calculation

$$
S T=S t o * e^{-\left(\frac{A P W L}{S t o}\right)}
$$

Sto $=$ empirical number $(50 \mathrm{~mm})$

$\mathrm{e}=$ navier number $(\mathrm{e}=2.718)$

8. Delta Soil Moisture Storage calculation

$\Delta S T=\mathrm{ST}$ present month - ST previous month (8)

9. Actual Evapotranspiration calculation

To obtain AET start with defining wet months $(\mathrm{P}>\mathrm{PE})$ and dry months $(\mathrm{P}<\mathrm{PE})$ :

AET value for wet months: $\mathrm{AET}=\mathrm{PET}_{\text {adjusted }}$

AET value for dry months: $\mathrm{AET}=\mathrm{P}-\Delta S T$

10. Calculation of percolation (PERC)

Percolation for wet months:

$$
P E R C=\left(I-P E T_{\text {adjusted }}\right)-\Delta S T
$$

Percolation for dry months:

$$
\mathrm{PERC}=0
$$

11. Equation control

$$
P=P E R C+\triangle E T+\Delta S T+R O
$$

b) Leachate quality assessment

To assess whether leachate generation from treatment plants conform to the regulation standard leachate sampling conducted in inlet channel, each treatment lagoon and the outlet channel. Leachate sampling conducted in dry season in August and the sampling method used is based on SNI 6989.59:2008.

\subsubsection{Data analysis stage}

After the data processed, these results is analyzed using comparative and descriptive analysis Leachate quantity and quality assessments were compared to regulation standards. Field survey results compared to the criteria designed. The comparative findings were then described to analyzed how significant parameter aspects influenced leachate characteristics in treatment plants, vice versa.

\section{Description of the study area}

\subsection{Landfill description}

The study conducted in Temesi landfill, Gianyar Regency, Province of Bali, Indonesia. With geographical coordinates of $8^{\circ} 33^{\prime} 44.1$ " South latitude and $115^{\circ} 21^{\prime} 01.3^{\prime \prime}$ East longitudes, the landfill has 4.2 hectares total area divided into two cell blocks.

Within its operational period, Temesi landfill has been renewed in twofold. First renovation conducted in 2011 due to landfill cell extended and the constructing of leachate treatment plants. The plants applied anaerobic biological treatment process comprise of: anaerobic pond - facultative pond - maturation pond - wetland. The plant designed to treat leachates that is estimated will be generates from $419 \mathrm{~m}^{3}$ volume of solid waste per day and it is operated at 2012 designed with controlled landfill operation system.

The second renovation occurred at 2014, an Anaerobic Baffled Reactors (ABR) is built as an additional treatment due to leachate quality sampling 
from the treatment plant is not conforming to the utilized standards. As seen in Figure 1.

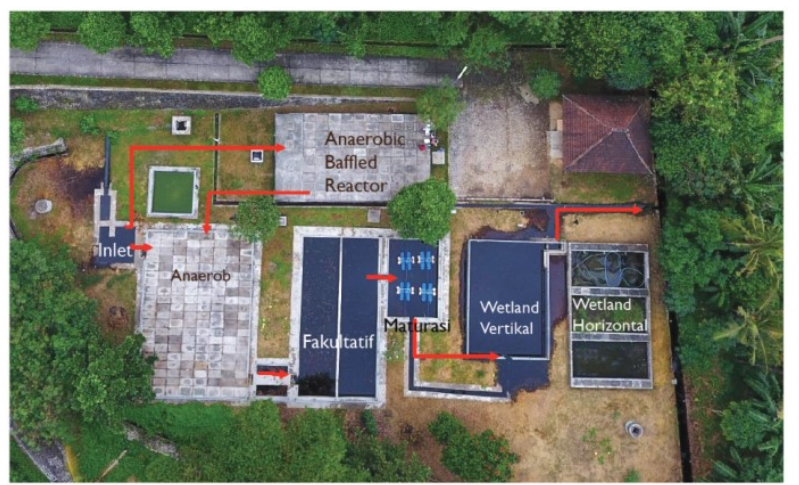

Fig.1. Leachate treatment plant aerial view in Temesi landfill [12]

Based on its standard operational maintenance, Temesi landfill has 4 main waste management activities, which are: a) organics waste composting; b) inorganics waste segregation; c) landfilling the residue; d) residue compaction with soil cover.

\subsection{Current landfill operational maintenance system condition}

and

From the field survey and observation, it is recognizing that current landfill operational and maintenance system is not suitable to the standard operational maintenance. Organic waste composting and inorganics waste segregation are still operated up to the survey conducted. These activities reduce about 33 tons of waste per day (equal to $15 \%$ of the total solid waste volume) [13]. The heavy equipment was un-operated, hence the residue goes to the landfill without compaction and covering soil activities, in other words the landfill currently practiced an open dumping system. Both landfill cells filled with approximately 5 meters height of waste-piles.

Temesi landfill is not equipped with weighbridge, the waste weighting is manually calculated by estimating the volume from each garbage truck. The presumptuous weight standards utilized are: a) a full-loaded garbage truck is presumed to be equal to $6 \mathrm{~m}^{3}$ waste volume; b) an over loaded garbage truck (30-60 over tall from the garbage top) is presumed to be equal to $8 \mathrm{~m}^{3}$ waste volume; c) a half or two-third loaded garbage truck is presumed to be equal to $4 \mathrm{~m}^{3}$ waste volume. From the practice revealed, it is indicating that it needs further investigation for waste generation volume data accuracy.

\subsection{Current leachate treatment plants condition}

As previous described leachate treatment plants in Temesi landfill has been revitalized due to treatment efficiency enhancement. Yet, both treatment plants applied similar treatment process which is biological treatment, due to some considerations amongst other: particularly designed to remove organics, wastewater is treated by natural occurring processes: solar light, wind and microorganism [14] which indicate to low budget operations and suitable to tropical climate country.

The first leachate treatment plants applied are comprised of: anaerobic pond - facultative pond maturation pond - wetland. Two years later, the treatment plant is renovated comprised of: Anaerobic Baffled Reactors (ABR) - anaerobic/stabilize pond facultative pond - maturation pond - vertical wetland horizontal wetland. The leachate collection pipe from landfill to treatment plants is detached from anaerobic pond and connected to ABR. In the current treatment plant, the leachate preliminary treated in ABR and connected to anaerobic pond for the next treatment. From the describing above, the treatment plants are combination between the $2^{\text {nd }}$ and $3^{\text {rd }}$ treatment plants alternatives based on law number 3 year 2013 Ministry of Public Works.

The ABR designed with total 11 up-flow compartments, attached with bio ball fixed media in the ninth and tenth compartments to growth microorganisms aimed to dissolved organics loading.

The anaerobic pond was then functioned as stabilization pond to enhance COD removal efficiency. The leachate effluent from anaerobic pond was then treated respectively in facultative pond and maturation pond where there are four windmills constructed in the maturation ponds for aeration. Final treatments to assure leachate disposal is safe to flow to the water body are vertical and horizontal wetlands.

When the leachate sampling conducted, physical condition of leachate treatment plants are as followed: leachates has yellow brown colour in the inlet and dark colour in the outlet, leachates inundate surround the treatment plants, also overflows to the drainage channel that border the treatment plants. The borders material which made of steel, are corrosive caused by its direct contact to leachate, the condition indicated that either there are leakages in between influent or effluent pipe, or there has been clogging caused by sludge that hasn't been removed for a long time.

The air pipes around the ABR treatment were in broken condition, and the windmills in the maturation pond are not well functioned. The conditions of vertical and horizontal wetlands are filled of tall grass. From over all condition, it is shown that the leachate treatment plants are not well maintained and evidently influenced the treatment plant performance.

\section{Result and Discussions}

\subsection{Leachate treatment plants dimension, $\mathrm{pH}$ and temperature value}

There are few data obtained from direct observation. Leachate treatment plants dimension, $\mathrm{pH}$ and temperature value are displayed in Table 4 below. 
Table 4. Temesi leachate treatment plant dimension, $\mathrm{pH} \&$ temperature value

\begin{tabular}{|c|c|c|c|c|c|}
\hline \multirow{2}{*}{ Pond } & \multicolumn{3}{|c|}{ Dimension (m) } & \multicolumn{2}{c|}{$\begin{array}{c}\text { Direct measure } \\
\text { parameters }\end{array}$} \\
\cline { 2 - 6 } & $\mathbf{l}$ & $\mathbf{w}$ & $\mathbf{d}$ & $\mathbf{p H}$ & $\begin{array}{c}\text { Temp. } \\
\left({ }^{\circ} \mathbf{C}\right)\end{array}$ \\
\hline ABR & 15.5 & 8.5 & - & 8 & 31.8 \\
\hline Anaerobic & 15 & 10 & 3.4 & 9 & 31.7 \\
\hline Facultative & 15 & 3.6 & 2.37 & 9 & 29 \\
\hline Maturation & 7.5 & 5 & 2.9 & 9 & 28 \\
\hline Wetland & 10.7 & 7.5 & 2.6 & 9 & 29.3 \\
\hline
\end{tabular}

The height dimension for the ABR pond is not accessible because the covering plate was sealed. Therefore, the ABR height is adopted from As Built Drawing document. From the measured dimension in Table 3, the actual volume can be calculated and displayed in Table 5.

Table 5. Dimension and actual volume Temesi leachate treatment plant

\begin{tabular}{|c|c|c|c|c|c|}
\hline $\begin{array}{c}\text { Treatment } \\
\text { pond }\end{array}$ & Unit & $\mathbf{L}(\mathbf{m})$ & $\mathbf{W}(\mathbf{m})$ & $\mathbf{D}(\mathbf{m})$ & $\mathbf{V}\left(\mathbf{m}^{3}\right)$ \\
\hline ABR & 1 & 15.5 & 8.5 & 2 & 263.5 \\
\hline Anaerobic & 1 & 15 & 10 & 3.4 & 510 \\
\hline Facultative & 2 & 15 & 3.6 & 2.37 & $2 \times 121.6$ \\
\hline Maturation & 1 & 7.5 & 5 & 2.9 & 108.8 \\
\hline Wetland & 1 & 10.7 & 7.5 & 2.6 & 209.6 \\
\hline
\end{tabular}

It can be seen from Table 4 that the actual temperature particularly from $\mathrm{ABR}$ and anaerobic is excessing $30^{\circ} \mathrm{C}$ means it is completing the requirement for optimum performance [15].

From the calculating actual volume in Table 5, the subsequent step is to determine detention time (Td) from each pond unit. To attain the calculation of detention time, majorly we need to calculate the leachate quantity (debit rate).

\subsection{Leachate flowrate assessment}

Using the Thornthwaith method, the leachate flowrate or leachate percolations in Temesi landfill is calculated. With several parameters utilized for the water balance calculation obtained from Table 2 and Table 3 as followed:

- Landfill soil cover type: sandy loam

- Available water for sandy loam type: $150 \mathrm{~mm} / \mathrm{m}$

- Applied soil cover thickness: $30 \mathrm{~cm}=0.3 \mathrm{~m}$

- Coefficient runoff (Cro): 0.1 - 0.15 (median value 0,125 ; to be used for final debit rate calculation)

- From the previous parameters, Soil Moisture Storage (ST) is calculated: $150 \mathrm{~mm} \times 0.3 \mathrm{~m}=45 \mathrm{~mm}$

- Maximum soil moisture storage (STo) water from empirical table: $50 \mathrm{~mm}$

Supporting data above is applied to calculate leachate percolation rate in Table 6 below.

Table 6. Thornthwaite leachate percolation calculation in Temesi landfill

\begin{tabular}{|c|c|c|c|c|c|c|c|c|c|c|c|c|c|}
\hline Parameter & Jan & Feb & Mar & Apr & Mei & Juni & Juli & Ags & Sep & Okt & Nov & Des & Jumlah \\
\hline Temperatur & 27,8 & 27,9 & 28,1 & 28,2 & 28,0 & 27,3 & 26,6 & 26,5 & 26,8 & 27,9 & 28,4 & 27,9 & \\
\hline Indeks panas & 13,43 & 13,49 & 13,62 & 13,75 & 13,56 & 13,04 & 12,55 & 12,48 & 12,69 & 13,53 & 13,87 & 13,51 & 159,53 \\
\hline PET $(\mathrm{cm})$ & 16,07 & 16,26 & 16,68 & 17,13 & 16,48 & 14,82 & 13,34 & 13,14 & 13,76 & 16,40 & 17,55 & 16,30 & \\
\hline PET (mm) & 160,71 & 162,55 & 166,84 & 171,29 & 164,85 & 148,23 & 133,44 & 131,45 & 137,62 & 163,97 & 175,45 & 163,03 & \\
\hline Daylight factor & 1,074 & 0,964 & 1,047 & 0,993 & 1,013 & 0,969 & 1,006 & 1,016 & 1,000 & 1,057 & 1,044 & 1,088 & \\
\hline PET adjusted & 172,64 & 156,73 & 174,70 & 170,07 & 166,98 & 143,59 & 134,22 & 133,52 & 137,62 & 173,34 & 183,20 & 177,45 & \\
\hline $\mathrm{P}(\mathrm{mm})$ & 348,0 & 257,3 & 161,7 & 93,3 & 215,7 & 182,1 & 147,8 & 91,1 & 123,9 & 105,9 & 129,6 & 228,3 & 2084,7 \\
\hline $\mathrm{CRO}$ & 0,125 & 0,125 & 0,125 & 0,125 & 0,125 & 0,125 & 0,125 & 0,125 & 0,125 & 0,125 & 0,125 & 0,125 & \\
\hline RO & 43,5 & 32,2 & 20,2 & 11,7 & 27,0 & 22,8 & 18,5 & 11,4 & 15,5 & 13,2 & 16,2 & 28,5 & 261 \\
\hline I & 304,5 & 225,1 & 141,4 & 81,6 & 188,7 & 159,3 & 129,3 & 79,7 & 108,4 & 92,7 & 113,4 & 199,8 & 1824 \\
\hline I-PETadjusted & 131,9 & 68,4 & $-33,3$ & $-88,4$ & 21,8 & 15,7 & $-4,9$ & $-53,8$ & $-29,2$ & $-80,6$ & $-69,8$ & 22,3 & \\
\hline APWL & 0 & 0 & $-33,3$ & $-121,7$ & 0 & 0 & 0 & $-53,8$ & $-83,1$ & $-163,7$ & $-233,5$ & 0 & \\
\hline ST & 50 & 50 & 26,8 & 4,8 & 50 & 50 & 50 & 16,1 & 9,2 & 1,8 & 0,5 & 50 & \\
\hline AST & 0 & 0 & $-23,2$ & $-22,1$ & 0 & 0 & 0 & $-33,9$ & $-6,9$ & $-7,3$ & $-1,4$ & 0 & \\
\hline AET & 172,6 & 156,7 & 118,2 & 59,5 & 167,0 & 143,6 & 134,2 & 45,8 & 101,5 & 85,4 & 112,0 & 177,4 & 1474,1 \\
\hline PERC & 131,9 & 68,4 & 0 & 0 & 21,8 & 15,7 & $-4,9$ & 0 & 0 & 0 & 0 & 22,3 & \\
\hline
\end{tabular}

Wet months ( $\left.\mathrm{P}>\mathrm{PE}_{\text {adjusted }}\right)$ : January, February, March, April, Sept, November, December (9 month). Dry months ( $\left.\mathrm{P}>\mathrm{PE} \mathrm{E}_{\text {adjusted}}\right)$ : May, August, October (3 month). From Table 5 the value of maximum percolation is in January $131.9 \mathrm{~mm}(0.132 \mathrm{~m})$ with $1.03 \mathrm{Ha} / 10300 \mathrm{~m}^{2}$ landfill area, the debit rate in Temesi landfill calculated as followed:
$\mathrm{Q}_{\text {leachate }}=\mathrm{A} *(1-\mathrm{Cro}) *$ Perc $\max$.

$=10300 \mathrm{~m}^{2} *(1-0.125) * 0.132 \mathrm{~m}$

$=1188.7 \mathrm{~m}^{3} /$ month $=39.625 \mathrm{~m}^{3} /$ day

$=0.00005 \mathrm{~m}^{3} / \mathrm{sec}=0.4586 \mathrm{Litre} / \mathrm{sec}$

$=0.45 \mathrm{Litre} / \mathrm{sec}$ on $10300 \mathrm{~m}^{2}$ landfill area 
From Table 5 and Table 6 the detention time for each treatment pond were obtained and display in Table 7 below.

Table 7. Calculation of detention time in Temesi leachate treatment plant

\begin{tabular}{|c|c|c|}
\hline Treatment pond & $\mathbf{V}\left(\mathbf{m}^{\mathbf{3}}\right)$ & $\begin{array}{c}\text { Time detention } \\
(\mathbf{T d})\end{array}$ \\
\hline ABR & 263.5 & 7 days \\
\hline Anaerobic & 510 & 13 days \\
\hline Facultative & $2 \times 121.6$ & 6 days \\
\hline Maturation & 108.8 & 3 days \\
\hline Wetland & 209.6 & 5 days \\
\hline
\end{tabular}

Table 4 shown detention times from each treatment are very short. It does not meet the design criteria standard Law number 3/2013 Ministry of Public works.

\subsection{Comparative Analysis to Regulation Standards}

To identify whether the leachate treatment plant in Temesi landfill accomplishing the requirements in the standard number 3 year 2013 Ministry of Public Works, the comparative between the design criteria and the standard mentioned is display in Table 8 below.

Table 8. Temesi leachate treatment plant design criteria comparative analysis

\begin{tabular}{|c|c|c|c|c|}
\hline \multirow{2}{*}{$\begin{array}{c}\text { Treatment } \\
\text { pond }\end{array}$} & \multicolumn{2}{|c|}{ Design criteria } & \multicolumn{2}{c|}{ Regulation standard } \\
\cline { 2 - 5 } & $\begin{array}{c}\text { Depths } \\
(\mathbf{m})\end{array}$ & $\begin{array}{c}\text { Detention } \\
\text { time (Td) }\end{array}$ & $\begin{array}{c}\text { Depths } \\
\text { (m) }\end{array}$ & $\begin{array}{c}\text { Detention } \\
\text { time (Td) }\end{array}$ \\
\hline ABR & 2 & 7 days & $2-4$ & $1-2$ days \\
\hline Anaerobic & 3.4 & 13 days & $2.5-5$ & $\begin{array}{c}20-50 \\
\text { days }\end{array}$ \\
\hline Facultative & 2.37 & 6 days & $1-2$ & $\begin{array}{c}5-30 \\
\text { days }\end{array}$ \\
\hline Maturation & 2.9 & 3 days & $1-1.5$ & $\begin{array}{c}7-20 \\
\text { days }\end{array}$ \\
\hline Wetland & 2.6 & 5 days & $0.1-0.6$ & $\begin{array}{c}4-15 \\
\text { days }\end{array}$ \\
\hline
\end{tabular}

From the above Table 8 it is shown that ABR unit detention time is 5 days longer than the standard set. Seeing from the ABR designed with 11 compartments it is assuming aimed to maximizing hydraulic retention time (HRT) and minimizing the up-flow velocity to reduce solids carry over [16], the detention time should be shorter, because in ABR the contact time between any microorganism and the pollutants is less. ABR design note is not available in this study, hence the designed HRT is unknown.

Vice versa, detention time in anaerobic pond is much shorter than the standard. It is similar in maturation and wetland pond. Shorter detention time will increase the organic surface loading [17], this influenced to poorer effluent quality.

Further analysis, if we observed the depth from each pond it is shown that the depth of maturation pond is 2.9 meter where it is exceeding the requirement standard from criteria designed and Law number 3/2013 Ministry of public works which produce optimum performance at 1.5 meter depth or less. Evidently, shallower maturation pond was more efficient at microbiogical disinfection than the deeper maturation pond [17]. We can relate the above analysis to the leachate effluent quality that will be discussed in the next chapter.

\subsection{Leachate quality assessment}

\subsection{1. $B O D_{5}$ and $C O D$ value assessment}

From five treatment ponds leachate sampling, it is found that the $\mathrm{BOD}_{5}$ and $\mathrm{COD}$ value is $>2000 \mathrm{mg} / \mathrm{L}$. It is shown respectively in Figure 2 and Figure 3 below.

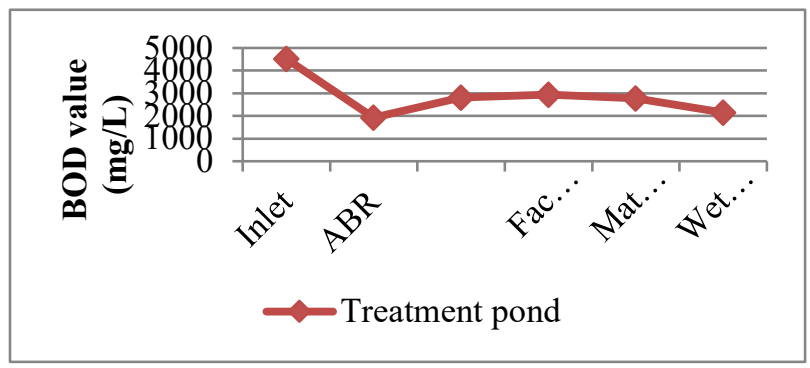

Fig.2. $\mathrm{BOD}_{5}$ value in Temesi leachate treatment plant

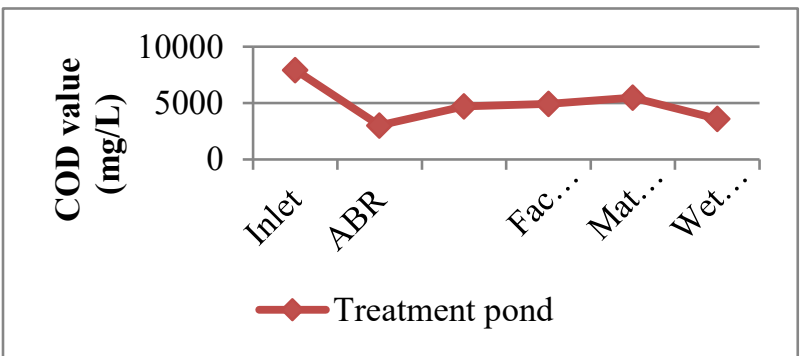

Fig.3. $\mathrm{COD}_{5}$ value in Temesi leachate treatment plant

From Figure 2 and Figure 3 above it is shown that $\mathrm{BOD}_{5}$ and COD value significantly reduced from inlet to ABR treatment. While in subsequent treatment from anaerobic to maturation pond shown that $\mathrm{BOD}_{5}$ and COD value tend to be increasing, although there has been a decrease value from maturation to wetland pond. The result indicating that the organics removal in each pond is not well performed. Further investigation is needed particularly for anaerobic pond performance that shown there has been a significant amount of BOD and COD value increasing.

Seeing from the age of the landfill refuse, the leachate derived from 5 year old landfill. If we relate leachate $\mathrm{BOD}_{5}$ and $\mathrm{COD}$ value to the landfill age, the landfill is categorized in between young (less than 2 years) and mature landfill (greater than 10 years) [3].

\subsubsection{TSS and $N$ total value assessment}

Total Suspended Solids (TSS) is referred to as nonfilterable residue. Mean that the less TSS contained in leachate effluents, the better. The result of TSS value 
from Temesi leachate treatment plants is shown in Figure 4.

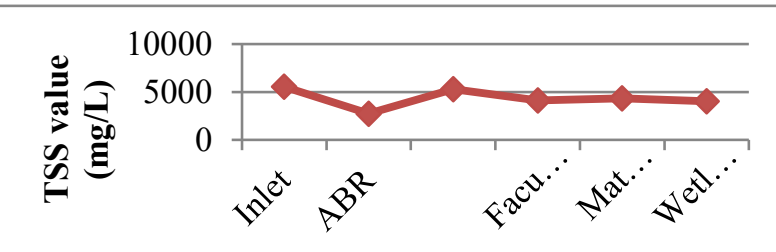

Treatment pond

Fig.4. TSS value in Temesi leachate treatment plant

From Figure 4 it is shown that the data trend almost similar to leachate $\mathrm{BOD}_{5}$ and $\mathrm{COD}$ values. The TSS from influent leachate is significantly decreasing in ABR pond and increasing in anaerobic pond. Under operational conditions, anaerobic filters were sometimes clogged due to iron and calcium precipitation [18], which needs further investigation. Yet, from the phenomenon, we assume that anaerobic pond is in low efficiency performance.

Following is the TSS value from anaerobic pond to wetland pond. It can be seen that the TSS value is reduced significantly although it remains in great amount. below

For the leachate $\mathrm{N}$ total value is displayed in Figure 5

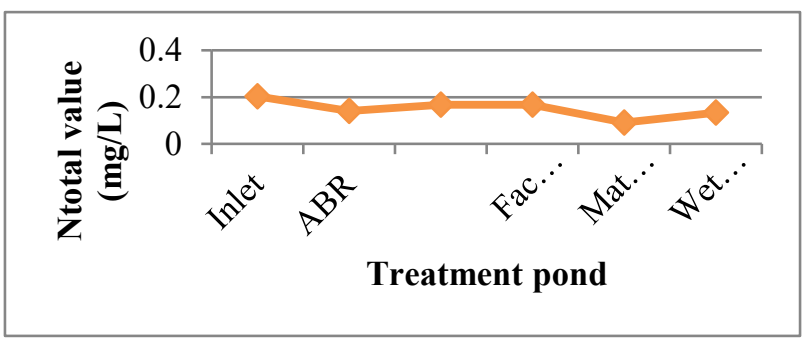

Fig.5. $\mathrm{N}$ total value in Temesi leachate treatment plant

From Figure 5 it is shown the $\mathrm{N}$ total amount is significantly reduced in ABR pond and from facultative to maturation pond. Yet, it is surprisingly increasing in wetland. What we need to emphasise is that $\mathrm{N}$ total value are low, due to the $\mathrm{BOD}_{5}$ and $\mathrm{COD}$ high value we also need further investigate to know whether the treatment plants has sufficient nitrogen to decompose the organics.

\subsubsection{Comparative analysis to regulation standard}

From the overall leachate quality assessment, we can compare the result to the regulation standard as followed.

Table 9. Temesi landfill leachate quality assessment compare to regulation standard

\begin{tabular}{|c|c|c|c|c|c|c|c|}
\hline \multirow{2}{*}{ Parameters } & \multicolumn{9}{|c|}{ Treatment pond } & \multirow{2}{*}{ Standards } \\
\cline { 2 - 9 } & Inlet & ABR & Anaerobic & Facultative & Maturation & Wetland & \\
\hline $\mathrm{pH}$ & 8.48 & 8.305 & 8.47 & 8.395 & 8.335 & 8.315 & $6-9$ \\
\hline BOD & 4515 & 1927 & 2810 & 2937 & 2785 & 2145 & 150 \\
\hline COD & 7938 & 3024 & 4725 & 4914.2 & 5481.3 & 3591.1 & 300 \\
\hline TSS & 5537.47 & 2743.43 & 5301.25 & 4096.34 & 4321.65 & 4039.84 & 100 \\
\hline N Total & 0.203 & 0.14 & 0.168 & 0.168 & 0.091 & 0.133 & 60 \\
\hline Mercury (Hg) & 0,009 & $\mathrm{ttd}$ & $\mathrm{ttd}$ & $\mathrm{ttd}$ & $\mathrm{ttd}$ & $\mathrm{ttd}$ & 0.005 \\
\hline $\begin{array}{c}\text { Cadmium } \\
\text { (Cd) }\end{array}$ & 0.131 & $\mathrm{ttd}$ & 0.101 & 0.116 & 0.104 & 0.11 & 0.1 \\
\hline
\end{tabular}

From Table 9 above it is shown that leachate quality from leachate treatment plants in Temesi landfill does not meet the standards regulation number $p .59$ year 2016 by Ministry of Environmental and Forestry, except for the $\mathrm{N}$ total and Mercury parameter, which need further investigation.

As seen, the significant organics removal only occurred in ABR pond.

\subsubsection{Leachate treatment plants efficiency analysis}

From the overall leachate quality assessment, we can analyse the leachate treatment plants efficiency in Table 10 as followed.
Table 10. Treatment efficiency in Temesi leachate treatment plant

\begin{tabular}{|c|c|c|c|c|c|}
\hline \multirow{2}{*}{$\begin{array}{c}\text { Treatment } \\
\text { plant }\end{array}$} & \multicolumn{3}{|c|}{ Parameter } & \multirow{2}{*}{$\begin{array}{c}\text { Efficiency } \\
\text { standard } \\
(\%)\end{array}$} & \multirow{2}{*}{$\begin{array}{c}\text { Treatme } \\
\text { nt } \\
\text { Efficien } \\
\text { cy } \\
\end{array}$} \\
\hline & BOD & COD & TSS & & \\
\hline Inlet & 4515 & 7938 & 5537.5 & - & \\
\hline $\mathrm{ABR}$ & 1927 & 3024 & 2743.4 & $90-95$ & $50-60$ \\
\hline Anaerobic & 2810 & 4725 & 5301.3 & $60-80$ & - \\
\hline Facultative & 2937 & 4914.2 & 4096.3 & $75-90$ & - \\
\hline Maturation & 2785 & 5481.3 & 4321.7 & 50 & - \\
\hline Wetland & 2145 & 3591.1 & 4039.8 & 50 & $20-30$ \\
\hline
\end{tabular}


From Table 10 above it is shown that $\mathrm{ABR}$ pond with the highest efficiency up to $50-60 \%$ efficiency. Nevertheless, it does not meet the regulation standards.

\section{Conclusions}

From the Thornthwaite method, leachate flow rate acquired $0.45 \mathrm{~L} /$ second which is exceeding the leachate designed estimation $0.42 \mathrm{~L} /$ second. Some aspects that influenced the leachate generation rates amongst others: the open dumping operational system and geometry design of the treatment plant. Associated to the landfill operation process, the open dumping practice and the absence of soil cover will caused the leachate quantity increasing. The degree of density of the compacted refuse was found to be important factor that controls leachate generation rates [19], where Temesi landfill in un-operated compaction condition.

The treatment plants design in Temesi landfill particularly maturation pond is found to be deeper than the designed criteria. This has big influenced to its performance due to pathogen removal. It is indicating that carefully plan treatment include dimension also can be factors that influenced. It is evidently seen from the result of the effluent quality where the faecal coliforms still detected.

Overall result of leachate quality assessment does not meet the regulation standards by Law Number p.59 year 2016 Minstry of Environmental and Forestry.

From the field observation compare to the criteria designed it is found that leachate treatment plants in the field do not match to the design criteria. These are influenced the performance and efficiency of the treatment plant.

Findings in field survey such as: physical condition of leachate colour, landfill operational is not equipped with weighting bridge, the refuse volume is estimated by inaccurate method, un-operated heavy equipment, the absence of soil cover and compaction, the absence for sludge removal, and rare leachate re circulation evidently shown that the operation and maintenance practices were not performed well.

From the describing above, it can be concluded that the influenced aspects based on Law number 3 year 2013 Ministry of Public Works regarding Provision of Facilities and Infrastructure in Handling Household Waste which are: landfill operation, rainfalls, treatment plant designs, operation and maintenance practices are significantly influenced the leachate characteristics in leachate treatment plants in Temesi landfill, Gianyar Regency, Bali Province, Indonesia.

The acknowledgement goes to Balai Penelitian dan Pengembangan Wilayah II Denpasar for the research funding. And also to Satuan Kerja Pengembangan Lingkungan Permukiman Directorate General Cipta Karya Province of Bali for permission and access to Temesi Landfill leachate treatment plants.

\section{References}

1. M. B. Mendoza, Leonora E. Ngilangil, Desiree A. Vilar. Chem. Engi. Trans. Groundwater and Leachate Quality Assessment in Balaon Sanitary Landfill in La Union, Northen Philippines. 56, 246252 (2017)

2. W. Purwanta, R. W. Soemantojo, S. Widanarko, S. Bismo. J. Tek. Ling. Uji Eliminasi Gas Metana (CH4) dengan Biofiltrasi pada Unggun Kompos dan Tanah Penutup Landfill. 1-10 (2012)

3. G. Tchobanouglous et.al. Integrated Solid Waste Management. (1993)

4. P. Kurukupan, O. Tubtimthai, C. Visvanatan, and J. Trankler. Workshop. Sustain. Man. Influence on Tropical Seasonal Variations Operation Modes and Waste Composition on Leachate Characteristics and Landfill Settlement. 199-208 (2003)

5. Md. W. Widyarsana. Ppt. Kajian Karakteristik Lindi pada Instalasi Pengolah Lindi di Indonesia. (2016)

6. Peraturan Menteri Lingkungan Hidup dan Kehutanan RI. Nomor P.59/Menlhk/Setjen/Kum.1/2016 Tentang Baku Mutu Lindi bagi Usaha Dan/Atau Kegiatan Tempat Pemrosesan Akhir Sampah. (2016)

7. Peraturan Menteri Pekerjaan Umum RI. Nomor 03/PRT/M/2013. tentang Penyelenggaraan Prasarana dan Sarana Persampahan dalam Penanganan Sampah Rumah Tangga dan Sampah Sejenis Sampah Rumah Tangga. (2013)

8. C. Y. Xu, D. Chen. Hydrol Process. Comparison of Seven Model for Estimation of Evapotranspiration and Groundwater Recharge Using Lysimeter Measurement Data in Germany. 3717-3734 (2005)

9. E. Damanhuri. Diktat Landfilling Limbah. Bagian 7 Pengelolaan Leachate (Lindi). FTSL ITB. (2008)

10. D. J. Fenn, K. J. Hanley,T. V. DeGEARE. Use of The Water Balance Method For Predicting Leachate Generation From Solid Waste Disposal Sites. EPA. (1975)

11. V.T. Chow. Handbook of Applied Hdyrology; A compendium of Water Resources Technology. (1964)

12. Satuan Kerja Pengembangan Penyehatan Lingkungan Permukiman, Direktorat Jenderal Cipta Karya, Kementerian Pekerjaan Umum dan Perumahan Rakyat (2016)

13. Dinas Lingkungan Hidup Kab. Gianyar Provinsi Bali. Laporan Akhir TPA Temesi. (2016)

14. G. B. B. Herath. Proceeding IIER Int. Conf. Bangkok, Thai. Leachate Treatment Using Stabilization Ponds in Tropical Environments. 1-4. (2016)

15. Sector Guidance Note IPPC. S5. 03. Guidance for The Treatment of Landfill Leachate. 76-192. (2007)

16. K. M. Foxon, C. A. Buckley. Guidelines for The Implementation of Anaerobic Baffled Reactors for On-site or Decentralized Sanitation. (2006) 
17. H. W. Pearson, D. D. Mara, H. A. Arridge. Wat. Sci. Tech. The Influence of Pond Geometry and Configuration on Facultative and Maturation Waste Stabilization Pond Performance and Efficiency. (1995)

18. R. Stegmann, K.U.Heyer, R. Cossu. Proceeding Sardinia. Leachate Treatment. Tenth International Waste Management and Landfill Symposium, Italy. (2005)

19. R. Stegmann, H.J. Enrig. Prog. Wat. Tech. Vol.12. pp 919-947. Operation and Design of Biological Leachate Treatment Plants. Britain. (1980) 